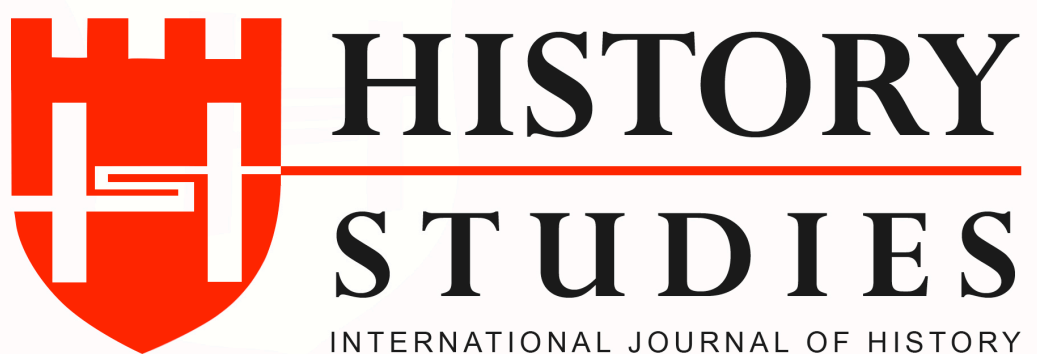

ISSN: 13094173 (Online) 1309 - 4688 (Print)

Volume 11 Issue 4, August 2019

DOI Number: 10.9737/hist.2019.757

Araştırma Makalesi

Makalenin Geliş Tarihi: 27.07.2019 Kabul Tarihi: 19.08.2019

Atıf Künyesi: Songül Dumlupınar Alican, "Şehre Ad Vermek: Âmid İsmi Hakkında”, History Studies, 11/4, Ağustos 2019, s. 1137-1152.

\title{
ŞEHRE AD VERMEK: ÂMID İSMI HAKKINDA•
}

\author{
To Give A Name to City: About Name of Amid
Dr. Songül DUMLUPINAR ALICAN
ORCID No: 0000-0002-1677-4778
Adlyaman Üniversitesi

\begin{abstract}
Öz: Köklü bir geçmişe sahip bulunan şehirlerin farklı tarihî dönemlerde farklı isimlerle anıldıkları bilinmektedir. Bunun nedenlerinden biri tarih içerisinde şehre hâkim olan farklı toplulukların isimlendirme biçimleridir. Her birinin kendilerine özgü kültürel yapıları, dinî ve sosyolojik geçmişleri ya da doğa anlayışları bu isimlendirme teşebbüsünde önemli bir faktör olarak öne çıkmaktadır. Bir diğer ifadeyle, her şehir kendisine hâkim olanlar tarafından değiştirilmek ve dönüştürülmek istenmiş, bu da doğal olarak şehirlerin isimlerine yansımıştır. Bununla birlikte bir şehre ad olan birçok ismin zaman zaman birbirlerinin bir tür devamı olarak bazı değişikliklerle yaşamaya devam ettikleri de not edilmelidir. Dolayısıyla her çağın isimlendirme pratiği üzerinden daha sonraki dönemlere şu ya da bu ölçüde bir miras bırakıldığı söylenebilir. Bu çalışmada, coğrafyamızın en köklü şehirlerinden Diyarbakır'ın, ortaçağdaki ismiyle ifade edilecek olursa Âmid'in tarihî süreç içerisinde deneyimlediği isim değişiklikleri ele alınacak ve değerlendirilecektir.
\end{abstract}

Anahtar Kelimeler: Ortaçağ, Diyarbakır, Âmid, İsim, Şehir, Kültür.

\begin{abstract}
It is known that cities with a long history are known by different names in different historical periods. One of the reasons for this is the nomenclature of different communities that have dominated the city throughout history. Their unique cultural structures, religious and sociological backgrounds or their understanding of nature stand out as an important factor in this naming attempt. In other words, each city was sought to be changed and transformed by those who dominated it, which was naturally reflected in the names of the cities. Therefore, it can be said that each era is inherited to one or more extent through the naming practice. It should be noted, however, that many names, which are the names of a city, sometimes survive each other as some kind of continuation of each other. In this study, will be discussed and evaluated Diarbakr's (Amid, with medieval name) names, it one of the most rooted cities of our geography, and its changes experienced in history.
\end{abstract}

Keywords: Medieval, Diarbakr, Amid, Name, City, Culture.

Bu çalışma, Adıyaman Üniversitesi Sosyal Bilimler Enstitüsü’nde Doç. Dr. Ünal Taşkın'ın danışmanlığında hazırlanan ve 28 Mayıs 2019'da savunulan “Ortaçağda Âmid (Diyarbakır)" başlıklı doktora tezinden üretilmiştir. 


\section{Giriș}

Bir şehrin tarihini kaleme alma sürecinde, şehrin coğrafi konumu veya tarihî coğrafyası kadar, hatta bazen çok daha önemli olan bir başka özelliği de oranın ismidir. Bunun nedeni ise elbette ismin kendisinin de ötesinde, içerisinde taşımakta olduğu simgesel anlamdır. Özellikle tarihî bakımdan köklü olan şehirlere bakıldığında, bu tür şehirlerin fiziksel mekânlarının tarihî eser ve somut kalıntılarla yüklü olması gibi, isimlerinin de birçok sosyal, siyasal, kültürel ve muhakkak dinsel anlamlarla yüklü olduğu görülür ve ismin bir anlamda şehrin tarihine şahitlik eden önemli bir kaynak olarak ele alınabileceği kolayca anlaşılır. Bunu, şehrin tarihî ve kültürel yapısının bir ölçüde orası için kullanılan isimler ile birlikte yaşadığının bir göstergesi olarak ele almak mümkündür. Bir şehrin ismi üzerine yapılacak iyi bir soruşturma ile örneğin coğrafyası, siyasî geçmişi, dinî ya da sosyal yapısı hakkında fikir edinmek imkân dâhilindedir. Dolayısıyla bir şehrin tarihini anlamaya öncelikle oranın isminden başlamak gerekir.

Şehre ad vermek orayı kuran, inşa eden, sosyal, siyasal, ekonomik ve kültürel bir merkez haline getiren toplumsal yapıların temel pratikleri arasındadır. Bu bakımdan bir şehre ismini ilk kez verenlerin oranın kurucuları olduğu söylenebilir. Bununla birlikte, söz konusu adlandırma pratiğinin siyasî güç ile ilişkili olduğu da belirtilmelidir. Nitekim köklü bir geçmişe sahip olan şehirlerin tarihleri boyunca birçok isimle anılması da bunu göstermektedir. Fatihler, kontrolleri altına aldıkları şehirlere yeni isimler verme konusunda her zaman istekli olmuş ve ele geçirmiş oldukları şehirlerin isimlerinin kendilerini yansıtmasını arzu etmişlerdir. Bununla birlikte bazen yeni isimlendirme girişimlerinin kalıcı olmadığ 1 ve halk tarafından kabul görmediği ya da hiçbir şekilde dikkate alınmadığı da görülmektedir. Fakat yine de bir şehri ele geçiren her topluluğun hiç olmazsa o şehrin mevcut adını kendi dillerine, lehçelerine ya da söyleyişlerine dönüştürüp bir anlamda kendi dillerine tercüme ettikleri de vurgulanması gereken bir durumdur. Metnimize konu olan Âmid isminin bütün bu değişim ve dönüşüm süreçlerine maruz kaldığ 1 söylenebilir.

Güneydoğu Anadolu'nun en önemli ve tarihî şehirleri arasında bulunan Diyarbakır için ortaçağlar boyunca kullanılan isim olan Âmid'in ele alındığ 1 bu çalışma, yukarıda temas etmiş olduğumuz çerçeve içerisinde şehrin "isim tarihinin" izini sürme çabasıyla kaleme alınmıştır. Bölgede bulunan diğer şehirler ile kıyas edildiğinde oldukça eski ve köklü bir tarihi olan şehrin binlerce yıllık geçmişinin resmini çekmek anlamına gelebilecek bu girişim, şehrin tarihî yönüne temas eden bir tarafa da sahiptir. Dolayısıyla da kronolojik bir veçheye sahip olacaktır. Şehrin kurulduğu ilk dönemlerden itibaren hangi isimlerle anıldığ 1 , bu isimlerin hangi temellere istinat ettiği ve nihai noktada nasıl bir dönüşüm süreci izlediği takip edilecektir. Dönemden döneme değişen isimlendirme pratiklerinin de tahlil edileceği çalışmada, aynı zamanda Âmid'in tek bir kültürü temsil etmediği ve üst üste yığılan ve biriken tarihî deneyimleri de aksettirdiği hususu gösterilecektir.

\section{Tarih Boyunca Âmid İçin Kullanılan İsimler}

Ortaçağ İslâm kaynaklarında ilk harfi "elif"in üstün harekesinin yanı sıra med işareti ile birlikte, ikinci harfi olan "mim"in esreli ve son harfi "dal"in cezimli olarak Âmid şeklinde okunduğu kaydedilen ${ }^{1}$ Âmid şehri için tarih boyunca birçok ismin kullanıldığı görülmektedir. Bugün Diyarbakır ismiyle bilinen şehrimizin merkezine, halen ayakta olan surların içerisinde

${ }^{1}$ Yâkût el-Hamevî, Mu'cemu'l-Büldân, I, thk. İhsan Abbas. Beyrut, 1977, s. 56-57; Safiyyüddîn Abdülmümin b. Abdülhakk el-Bağdâdî, Merâsıdu'l-Ittilâ' Alâ Esmâi'l-Emkineti ve'l-Bekâ', I, thk. Ali Muhammed el-Becâvî, Beyrut 1992, s. 6; Ebû Ubeyd Abdullah b. Abdülazîz Bekrî, Mu'cem Ma'ste'cem Min Esmâi'l-Bilâdi ve'l-Mevâzu', II, thk. Mustafa es-Sekâ, Beyrut, trs, s. 93; Şeyh Ebû'l-Abbâs Ahmed el-Kalkaşendî, Subhu'l- 'Aşâ, IV, Kahire, 1914-1945, s. 324 . 
kalan bölgeye karşılık gelen Âmid için tarih boyunca kullanılan farklı isimlerin, hiç kuşkusuz şehre egemen olan ya da burada ikamet eden topluluklar tarafından kullanılan isimler olduğu bilinmektedir. Öte yandan şehre değişik dönemlerde farklı isimler verilmekle birlikte, bilinen ilk dönemlerinden itibaren şehrin Âmid ismi ya da bu ismin farklı varyantları ile adlandırıldığ da bir hakikati ifade etmektedir. Günümüzde halen şehir halkı tarafindan biraz da bozulmuş bir halde ve "elif" harfinin "ayn" șeklinde telaffuz edilmesiyle "Amid ya da "Amed biçimindeki kullanımın en azından belli ölçüde dolaşımda olduğu görülmektedir. Salt buradan hareketle bile şehir isimlerinin kendilerine özgü bir kadere sahip oldukları ileri sürülebilir.

Tarihî serüveni içerisinde muhtelif adlarla anılan Âmid'e bilindiği kadarıyla ilk kez Amedi (Amidu, Amidi) adını verenler Asurlulardır. ${ }^{2}$ Fakat bu adın daha sonraki dönemlerde yerini farklı isimlere bıraktığı da bilinmektedir. Şehir hakkındaki ilk derli toplu bilgilerin elde edilir olduğu Romalılar döneminde buraya Amida denilmiştir. Resmî bir belge mahiyetindeki ilk kayıt olarak, şu anda Petersburg'daki Kaiserlichen Müzesi'nde bulunmakta olup 222-235 yıllarına tarihlenen ve Marcus Aurelius Severus döneminde kesilen sikkenin üzerinde bulunan bu ismin ${ }^{3}$ kullanım alanının dikkate değer bir şekilde yaygın olduğu anlaşılmaktadır. Nitekim Ammianus Marcellinus gibi Romalı müellifler tarafından şehirden Amida adıyla söz edilmesi de Romalılar devri boyunda şehirden bu isimle söz edildiği anlamına gelmektedir. ${ }^{4}$

Âmid için kullanılan bir başka isim, 4. Yüzyılın ortasında İmparator Konstantinos'un burada gerçekleştirdiği büyük imar ve genişletme faaliyetlerinin ardından şehre isim olarak verdiği Augusta'dır. Bir anlama hatası olabileceğine işaret etmekle birlikte, bunun Constantia olduğu şeklinde de tek bir yerde rastladığımız rivayete de işaret edelim. ${ }^{5}$ Bununla birlikte sözü edilen bu isim uzun süre yaşamamış, bir süre sonra unutulmaya terk edilmiştir. ${ }^{6}$ Tarihsel süreç

${ }^{2}$ Şevket Beysanoğlu, Bütün Cepheleriyle Diyarbakır, Diyarbakır Sanayi ve Ticaret Odası Yayınları, İstanbul, 1963, s. 3; Canan Parla, Türk-İslam Şehri Olarak Diyarbakır, (Yayınlanmamış Yüksek Lisans Tezi), Hacettepe Üniversitesi Sosyal Bilimler Enstitüsü, Ankara 1990, s. 21; Canan Parla, "Osmanlı Öncesinde Diyarbakır: Kente Hakim Olanlar ve Bıraktıkları Fiziksel İzler," 1. Uluslararası Oğuzlardan Osmanlıya Diyarbakır Sempozyumu, 2022 Mayıs 2004-Diyarbakır, Bildiriler Kitabı, ed. Kenan Ziya Taş, Ahmet Kankal, Diyarbakır 2004, s. 247; EphremIsa Yousif, Mezopotamya'nın Yıldız Şehirleri, çev. Nihat Nuyan, Avesta Basın Yayın, İstanbul 2011, s. 60; İbrahim Yılmazçelik, XIX. Yüzyılın Illk Yarısında Diyarbakır, Türk Tarih Kurumu Yayınları, Ankara, 1995, s. 1, n. 2; Nurgül Yıldırım, "Yeni Asurca Belgelerde Geçen Amēdi Şehri," Ankara Üniversitesi Dil ve Tarih-Coğrafya Dergisi, C. 53, S. 2, 2012, s. 1; Ercüment Yıldırım, Pers Hakimiyetinin Bitiminden Bizans Hakimiyetinin Başlangıcına Kadar Olan Dönemdeki Antik Çă̆ Yazarlarının Eserlerinde Orta Fırat Bölgesi, (Yayınlanmamış Doktora Tezi), Selçuk Üniversitesi Sosyal Bilimler Enstitüsü, Konya 2011, s. 92.

${ }^{3}$ Parla, Türk-İslam Şehri Olarak Diyarbakır, s. 21; Parla, "Osmanlı Öncesinde Diyarbakır: Kente Hakim Olanlar ve Bıraktıkları İzler," s. 249.

${ }^{4}$ Ammianus Marcellinus, I, çev. John C. Rolfe, ed. T. E. Page, E. Capps, W. H. D. Rouse, Büyük Britanya, 1935 , indeks; Guy Le Strange, Doğu Hilafetinin Memleketleri (Mezopotamya, Iran ve Orta Asya), çev. Cengiz Tomar, Adnan Eskikurt, Yeditepe Yayınları, İstanbul 2015, s. 151; Beysanoğlu, Bütün Cepheleriyle Diyarbakır, s. 3; Beysanoğlu, Şevket Beysanoğlu, Anıtları ve Kitâbeleri İle Diyarbakır Tarihi, I, Başlangıçtan Akkoyunlulara Kadar, Diyarbakır Büyükşehir Belediyesi Kültür ve Sanat Yayınları, Ankara, 1998, s. 3; Parla, Türk-İslam Şehri Olarak Diyarbakır, s. 21; Yılmazçelik, XIX. Yüzyılın İlk Yarısında Diyarbakır, s. 1; Yıldırım, Hakimiyetinin Bitiminden Bizans Hakimiyetinin Başlangıcına Kadar Olan Dönemdeki Antik Çă̆ Yazarlarının Eserlerinde Orta Fırat Bölgesi, s. 92.

${ }^{5}$ Alexander Macbean, A Dictionary of Ancient Geography, London, 1773, s. 43. Burada Edward Gibbon'un da ismin biçimine işaret etmeden "Imparator Konstantinus kendi adını taşıma onurunu ona henüz vermişti" şeklindeki ifadesi zikredilmeye değerdir. Bkz. Edward Gibbon, Roma Imparatorluğu'nun Gerileyiş ve Çöküş Tarihi, II, çev. Asım Baltacıgil, B/F/S Yayınları, İstanbul, 1987, s. 108.

${ }^{6}$ Ammianus Marcellinus, I, s. 465; Abû'l-Farac, Gregory (Bar Hebraeus), Abû'l-Farac Tarihi, I, Süryaniceden İngilizceye çev. Ernest A. Wallis Budge, Türkçe çev. Ömer Riza Doğrul, Türk Tarih Kurumu Yayınları, Ankara, 1999, s. 136; Saîd Paşa, "Vilayetin Tarihçesi," Salnâme-i Vilâyet-i Diyârbekir, Dersaâdet 1302, s. 18; Albert Gabriel, Şarki Türkiye'de Arkeolojik Geziler, çev. İdil Çetin, Dipnot Yayınları, Ankara, 2014, s. 91; Beysanoğlu, Anıtları ve Kitâbeleri Ille Diyarbakır Tarihi, I, s. 3; Adnan Çevik, XI-XIII. Yüzyıllarda Diyâr-ı Bekr Bölgesi Tarihi, (Yayınlanmamış Doktora Tezi), Marmara Üniversitesi Türkiyat Araştırmaları Enstitüsü, İstanbul 2002, s. 75; Parla, 
içerisinde özellikle hükümdarlar tarafından adları değiştirilmek istenen birçok yerde görülen bu durum, şehir için kullanılan "yaygın bir biçimde kabul edilmiş" ismin konulmak istenen yeni isme bir şekilde baskın çıktığını ve değiştirilmek istenmesine adeta inatla karşı koyar gibi yaşamaya devam ettiğini ortaya koymaktadır. Nitekim Âmid şehri için tarih içerisinde kullanılan diğer isimlere bakıldığında, bunların hemen hemen tamamının şehrin antik dönemlere götürülen ilk ismi ile şu ya da bu biçimde bağlantılı olan isimler olduğu görülmektedir. Şehir isimlerinin, bu isimleri verenlerden bağımsız bir var olma biçimine sahip olması şeklinde tarif edebileceğimiz bu duruma, örneğin Âmid için bir dönem Yakutçada sikke anlamına geldiği bilinen "Amiday" isminin kullanıldığı ve yine İskenderiyeli meşhur Ptolemaios'un Dicle kıyısındaki şehirler arasında zikrettiği yahut genel manada Âmid olduğu düşünülen Ammaia'nın buraya verilen isimler arasında yer aldığı yönündeki iddialar da örnek olarak verilebilir. ${ }^{7}$ Yine burada bölgedeki bakır madeni adı ile ilişkili olduğu sanılan Amidağ adına da bir göndermede bulunmak gerekir. ${ }^{8}$

Âmid ya da Amida ismi ile ilişkilendirilebilecek olup şehir için kullanılmış olan adlar bu kadarla sınırlı değildir. Bizanslılar burası için Bilge Umar'ın "Amida" ismini kendi ağızları dolayımında söyleyişlerine bağladığı "Emet" ismini kullanmış, ${ }^{9}$ öte yandan bölgenin tarihî bakımdan en eski toplulukları arasında olan Süryânîler şehri kendi gelenekleri çerçevesinde isimlendirmiş ve zaman zaman Âmid de demelerine rağmen bazı kaynaklarda burası için gırtlaktan gelen "o" harfi ile "Omid", "Emit" ya da "Amide" gibi isimler kullanmışlardır. ${ }^{10}$ Yine şehir için Amot ya da Amat şeklinde bir kullanımın bulunduğuna dair yaklaşımların da olduğunu söyleyelim. Buna göre, Hititler döneminde bölgede hüküm süren Amat kabilesinden hareketle şehre bu isim verilmişti. ${ }^{11}$ Öte yandan başka bir yerden teyit edememiş olsak da, Yahudi literatüründe şehrin "Kalne" olarak isimlendirildiğine ve Tevrat'ta bu isimle geçen yerin bu şehir olduğuna ilişkin bir iddianın bulunduğunu burada zikretmek ilginç olabilir. ${ }^{12}$

Şehre dönük İslâmî dönemdeki isimlendirmelere bakıldığında, ortaçağda kaleme alınan eserlerde burası için yaygın olarak Âmid isminin kullanıldığı görülür. Kaynaklarda, aşağıda detaylı bir biçimde analiz etmeye çalışacağımız bazı "İslâmî referanslara" da sahip olduğu görülen bu kullanım biçiminin şehrin antik dönemlerdeki isimlendirmesi ile ilişkili olduğu açık bir biçimde görülmektedir. Bu bakımdan şehrin kadim isminin zaman içerisinde bir anlamda Müslümanlaştığı da söylenebilir. Nitekim Âmid isminin süreç içerisinde adeta yeni bir

Türk-İslam Şehri Olarak Diyarbakır, s. 21; Parla, "Osmanlı Öncesinde Diyarbakır: Kente Hakim Olanlar ve Bıraktıkları İzler," s. 247.

${ }^{7}$ Besim Darkot, "Diyarbekir", IA, III, Milli Eğitim Bakanlığı, y.y., trs., s. 602; Macbean, A Dictionary of Ancient Geography, s. 43; Mehmet Tezcan, "Hunların Anadolu'daki İlk Görünüşleri: 359 Tarihinde Amida Kuşatmasında Kionitler," 1. Uluslararası Oğuzlardan Osmanliya Diyarbakır Sempozyumu, 20-22 Mayls 2004-Diyarbakır, Bildiriler Kitabı, ed. Kenan Ziya Taş, Ahmet Kankal, Diyarbakır 2004 s. 104; Parla, Türk-İslam Şehri Olarak Diyarbakır, s. 21; Parla"Osmanlı Öncesinde Diyarbakır: Kente Hakim Olanlar ve Bıraktıkları İzler," s. 247; AsnuBilban Yalçın, "VI. Yüzyılda Roma İmparatorluğu'nun Doğu Sınırları ve Amida (Diyarbakır) Kenti”, 1. Uluslararası Oğuzlardan Osmanliya Diyarbakır Sempozyumu, 20-22 Mayls 2004-Diyarbakır, Bildiriler Kitabı, ed. Kenan Ziya Taş, Ahmet Kankal, Diyarbakır 2004, s. 226.

${ }^{8}$ Yılmazçelik, XIX. Yüzyılın İlk Yarısında Diyarbakır, s. 1, n. 2.

9 Bilge Umar, Türkiye'deki Tarihsel Adlar, İnk1lap Kitabevi, İstanbul 1993, s. 242; Nejat Göğünç, "Onaltınc1 Yüzyılın İlk Yarısında Diyarbakır,” Belgelerle Türk Tarihi Dergisi, 7, 1968, s. 76.

${ }^{10}$ Beysanoğlu, Bütün Cepheleriyle Diyarbakır, s. 3; Beysanoğlu, Anıtlart ve Kitâbeleri İle Diyarbakır Tarihi, I, s. 3; Parla, Türk-İslam Şehri Olarak Diyarbakır, s. 21. Süryanilerin şehir için Omid ismini kullanmalarına ilişkin bir örnek için bkz. Mor Efrem, Kilise Ataları Tarafindan "Kutsal Ruh'un Kavalı" Olarak Adlandırılan Mor Efrem'in Şiirleri, I, (Tıpkıbasım ve tercüme), çev. Horiepiskopos Gabriel Akyüz, Kültür Bakanlığı Yayınları, Ankara 2012, s. 24.

${ }^{11}$ Beysanoğlu, Anıtları ve Kitâbeleri İle Diyarbakır Tarihi, I, s. 4.

12 Ali Melek, "Diyarbakır'da Peygamber Makam ve Kabirleri," Nebiler, Sahabiler, Azizler ve Krallar Kenti Diyarbakır Seтроzyumu, 25-27 Mayıs 2009-Diyarbakır, Bildiriler Kitabı, Ankara 2010, s. 23. 
etimolojik çerçeve edinmesi, farklı efsanevî rivayetlere konu olması ve yeni ekler alıp yeni veçheler kazanması da bu durum ile alakalıdır. Özellikle Türk hâkimiyeti döneminde ve 13. Yüzyıldan sonraki dönemde kaleme alınan eserlerde sözü edilen şehrin, örneğin 17. Yüzyılda buraya gelen Fransız seyyah Jean Baptiste Taverniver'in seyahatnamesinde olduğu gibi ${ }^{13}$ Kara Amid ya da Kara Hamid adı ile anılmasını veya Timur'un zaferlerini konu edinen zafernâme türündeki eserlerde şehrin Karaca Kale ve Kara Kale olarak adlandırılmasını ismin kültürel dönüşümüne örnek olarak vermek mümkündür. ${ }^{14}$ Bu noktada Evliya Çelebi'nin "defterhâne-i padişahîde de aynı şekilde anılmakta olan" şehre "Rûm tarihçilerin Kara Âmid demekte oldukları" yönündeki kaydını zikretmek de yerinde olacaktır. ${ }^{15}$

Âmid isminin tarihsel serencamı ile alakalı bir başka husus, İslâm medeniyetini teşkil eden kültürler arasındaki etkileşimi de yansıtmakta olan önemli bir gösterge olarak karşımıza çıkmaktadır. İlginç bir duruma tekabül eden bu husus, Türk hâkimiyeti döneminde meydana gelen şehir isimlendirmesinin (Kara Âmid-Kara Hamid) Arapçaya tercüme edilerek Âmid-i Sevdâ (Kara Âmid) biçiminde kullanılmasıdır. ${ }^{16}$ Bu kullanımı referans kabul eden Hacı Niyazi Bey'in (1856-1940) Amid-i Sevdâ isimli bir eser kaleme aldığını ve Ali Emiri Efendi'nin (1857-1924) de ilk sayısı 20 Şubat 1909 'da neşredilen aynı isimli bir dergi çıkardığını ilave edelim. ${ }^{17}$ Son olarak, bu bahis içerisinde Âmid için 18. Yüzyılda Diyârbekir ve Cumhuriyet döneminde de Diyarbakır adlarının kullanıldığını belirtmeden geçmeyelim. ${ }^{18}$

\section{2. Âmid İçin Kullanılan İsimlerin Tahlili}

Âmid isminin farklı biçimlerde de olsa şehri adlandırmak için tarihteki ilk kullanımı, M.Ö. 14. Yüzyılın sonu ile 13. Yüzyılın başında bölgeye hâkim olan Asur hükümdarı I. AdadNirari’nin döneminden kaldığı rivayet edilen bir kılıç kabzasında geçmektedir. ${ }^{19}$ Yine AdadNirari'nin Mitannilere karşı tertip ettiği seferi ile alakalı kayıtlarda, daha önce fethetmiş olduğu şehirlerin içerisinde, Aramiler tarafından kurulmuş olan Bit Zamani Krallığı'nın merkezi olarak Âmid ismi de yer almakta, ayrıca daha sonraki dönemlerde Asur idaresini yürüten mesela II. Asurnasirpal, II. Tukulti Ninurta, III. Salmanassar ya da V. Şamsi Adad gibi hükümdarlar

\footnotetext{
13 Jean-Baptiste Tavernier, Tavernier Seyahatnamesi, çev. Teoman Tunçdoğan, Kitap Yayınevi, İstanbul 2006, s. 287.

${ }^{14}$ Nizâmüddîn Şâmî, Zafernâme, çev. Necati Lugal, Türk Tarih Kurumu Yayınları, Ankara 1987, s. 184; Ca'ferî b. Muhammed el-Hüseynî, Târîh-i Kebîr (Tevârîh-i Enbiyâ ve Mülûk), çev. İsmail Aka, Türk Tarih Kurumu Yayınları, Ankara 2011, s. 24; Le Strange, Doğu Hilafetinin Memleketleri (Mezopotamya, Iran ve Orta Asya), s. 151; Beysanoğlu, Bütün Cepheleriyle Diyarbakır, s. 3; Beysanoğlu, Anıtları ve Kitâbeleri Ile Diyarbakır Tarihi, I, s. 3-4; Bedri Günkut, Diyarbekir Tarihi, Diyarbekir Basımevi, Diyarbakır, trs, s. 37; Parla, Türk-İslam Şehri Olarak Diyarbakır, s. 22.

${ }^{15}$ Evliya Çelebi, Seyahatnâme, $I V$, İkdam Matbaası, 1314, s. 24; Martin van Bruinessen, Hendrik Boeschoten, Evliya Çelebi Diyarbekir'de, İletişim Yayınları, İstanbul, 2009, s. 191; Max van Berchem, Josef Strzygowski, Gertrude Lowthain Bell, Amida, çev. Fatih Aygün, Bülent Özçelik, Hanide Türkseven, S. Erdem Türközü, Oriant Yayınları, Ankara 2015, s. 32; Gabriel, Şarki Türkiye'de Arkeolojik Geziler, s. 91; Günkut, Diyarbekir Tarihi, s. 37; Ejder Okumuş, "Evliya Çelebi'nin Seyahatnâme'sinde Diyarbakır," Osmanlı'dan Cumhuriyet'e Diyarbakır, I, ed. Bahaeddin Yediyıldız, Kerstin Tomenendal, Diyarbakır Valiliği ve Türk Kültürü’nü Araştırma Enstitüsü Yayını, Ankara 2008, s. 175; Parla, Türk-İslam Şehri Olarak Diyarbakır, s. 22.

${ }^{16}$ İmâdeddîn Muhammed b. Muhammed b. Hâmid el-Kâtib el-İsfahânî, el-Berku'ş-Şâmî, $V$, nşr. Ramazan Şeşen, İstanbul Üniversitesi Edebiyat Fakültesi Yayınları, İstanbul 1979, s. 59.

${ }^{17}$ Beysanoğlu, Anıtları ve Kitâbeleri İle Diyarbakır Tarihi, I, s. 4. Adı geçen dergi ile ilgili olarak bkz. Recep Tezgel, “1869-1969 Arası Diyarbakır'da Süreli Yayıncılık,” Uluslararası Diyarbakır Sempozyumu, 02-05 Kasım 2016-Diyarbakır, Bildiriler Kitabı, ed. Ufuk Bircan, Aytaç Coşkun, Mustafa Temel, Pınar Gürhan Kılıç, Diyarbakır 2017, s. 1100; Parla, Türk-İslam Şehri Olarak Diyarbakır, s. 22.

${ }_{18}$ Beysanoğlu, Bütün Cepheleriyle Diyarbakır, s. 4; Beysanoğlu, Anıtları ve Kitâbeleri İle Diyarbakır Tarihi, I, s. 5.

${ }^{19}$ Beysanoğlu, Anıtları ve Kitâbeleri İle Diyarbakır Tarihi, I, s. 3.
} 
döneminde de bu isim zikredilmektedir. ${ }^{20}$ Âmid ilk dönemlerde Asurluların Yukarı Dicle'yi tarif etmek için kullandıkları Nairi bölgesi şehirleri içerisinde yer alırken, M.Ö. 8. Yüzyıldan itibaren Bit Zamani devletinin merkezi olarak anılmaya başlanmıştır. ${ }^{21}$ Asur devri krali kayıtlarında yer aldığı biçimiyle Amidi, Amidu, Amida ya da Amedi şeklinde okunan ve M.Ö. 8. Yüzyıla tarihlenmekte olup bölgedeki Asur valilerinin isimlerini kayıt altına alan tarihi vesikalarda da geçen ismin, Yukarı Dicle havzasının ilk medeni halkı olduğu sanılan Hurrilerden kaldığı düşünülmektedir. ${ }^{22}$ Öte yandan daha önce de işaret ettiğimiz ve Amasya Tarihi isimli eseri ile bilinen Hüseyin Hüsameddin, Basri Konyar ve Bedir Günkut gibi isimlerin benimsediği Amot ya da Amat isminin de bu dönemlerin bir hatırası olup ismin Arapça imla ile Âmid'e dönüştüğü ileri sürülmektedir. ${ }^{23}$ İsmin antik dönemlerdeki kullanımı konusunda çağdaş kaynaklar üzerinden tespit edilmiş bir nedeni bilinmemektedir. Ancak bu ismin daha sonra Romalılar döneminde aldığı biçim olan Amida'nın çözümlenmesine ilişkin çabaların Âmid için de geçerli olduğu söylenebilir.

Romalılar döneminde ilk kullanımına Marcus Aurelius Severus döneminde kesilen sikkede tesadüf edilen Amida isminin şehrin klasik isminden hareketle oluştuğu açık olarak görülebilmektedir. Bununla birlikte, söz konusu kullanımın çözümlenmesine dönük bir kısım girişimlerin olduğunu da belirtmek gerekir. Bu girişimleri genel bir sıralama ile şu şekilde ele alabiliriz. Amida'nın "Diyarbakır kentimizin ilkçağdaki adı" olduğunu belirten Bilge Umar'a ait olan ilk çözümleme girişime göre, Amida isminin Amada, Amanda, Manda ve Mada gibi çeşitli türevleri bulunmaktadır ve kelime Ana Tanrıça “Ama”nın kök olarak kullanılışına "anda/ada/inda/ida" ekinin ilave edilmesiyle türemiş olup "Ama'ya tapanlar" anlamına gelmektedir. ${ }^{24}$ Doğru olup olmama ihtimalinden bağımsız olarak, kuşkusuz modern bir okuma biçimi olması dolayısıyla yaygın bir kabule mazhar olmadığını belirtmemiz gereken bu çözümlemenin dışında, Amida isminin kökenine dair başka değerlendirmeler de vardır. Süryani metropoliti Hanna Dolapönü'ye göre, Amida ismi Süryani dilinde "ümit" anlamına gelen "emed" kelimesinden türemiştir. Diyarbakır havalisindeki bazı köy isimlerinin Süryanice kökenli olduğunun bilinmesi ve halen bazı köylerde Âmid için Emid isminin kullanılması dolayısıyla Nejat Göyünç tarafından dikkate değer olarak görülen bu görüşün ne kadar sağlıklı olduğu kuşkusuz tartışılabilir, lâkin bu yaklaşımın her hâlükârda geriye dönük bir okuma biçimi olduğunu ve bu açıdan da her şeyden önce bir tür yakıştırma olduğunu akıldan çıkarmamak gerekir. ${ }^{25}$

Âmid şehri için kullanılan isimlerin arasında bulunan ve ismin ilk çağlardaki kullanımı ile benzerlik içerisinde olduğu görülen bir diğer isim ise Amiday'dır. Yakutçada "bakır sikke" anlamına gelen bir kelime olan bu ismin şehre neden ad olduğu düşüncesini anlamak zor değildir. Âmid, kuzeyinde yer alan Ergani ve Maden bölgelerindeki bakır yataklarına yakın olmasından dolayı tarihin erken dönemlerinden itibaren bir tür bakır piyasasının bulunduğu bir şehirdir ve sözünü ettiğimiz bu piyasa aynı zamanda şehrin isimlendirilmesinde belirleyici bir

\footnotetext{
${ }^{20}$ Yıldırım, "Yeni Asurca Belgelerde Geçen Amēdi Şehri," s. 2-3; Tuğba Türksoy, Demir Çă̆ı'nda Diyarbakır Bölgesi, (Yayınlanmamış Yüksek Lisans Tezi), Marmara Üniversitesi Sosyal Bilimler Enstitüsü, İstanbul 2007, s. 16-28.

${ }^{21}$ Yıldırım, "Yeni Asurca Belgelerde Geçen Amēdi Şehri,” s. 3; Türksoy, Demir Çağı'nda Diyarbakır Bölgesi, 26.

${ }^{22}$ Beysanoğlu, Anıtları ve Kitâbeleri Ille Diyarbakır Tarihi, I, s. 3; Yıldırım, "Yeni Asurca Belgelerde Geçen Amēdi Sehri," s. 1-2.

${ }^{23}$ Beysanoğlu, Anıtları ve Kitâbeleri İle Diyarbaktr Tarihi, I, s. 4.

${ }^{24}$ Umar, Türkiye'de Tarihsel Adlar, s. 62.

${ }^{25}$ Göğünç, "Onaltıncı Yüzyılın İlk Yarısında Diyarbakır," s. 76; İbrahim Özcoşar, "Diyarbakır'ın Kadim Cemaati: Süryaniler," Nebiler, Sahabiler, Azizler ve Krallar Kenti Diyarbakır Sempozyumu, 25-27 Mayıs 2009-Diyarbakır, Bildiriler Kitabı, Ankara 2010, s. 177.
} 
rol oynamıştır. ${ }^{26}$ Bununla birlikte, ne kadar akla yatkın gibi görünse de bu çözümlemenin de nitelik olarak yukarıdaki çözümleme gibi olduğunu, dolayısıyla da bir yakıştırma olarak görülmesi gerektiğini düşünüyoruz.

İslâm öncesi dönemde Âmid için kısa bir dönem kullanılan ve daha sonra da unutulan Augusta ismine de burada temas etmek gerekir. Yukarıda listelemiş olduğumuz isimlendirme biçimlerinden farklı olarak "yeni” bir isim olan Augusta, İmparator II. Konstantinos'un kendi şanına şan katmak için, bir anlamda şehirde yaptığı imar ve inşa faaliyetleri ile kendi kişisel varlı̆̆ını özdeşleştirmek için şehre verdiği bir isimdi. O dönem için son derece anlaşılabilir ve elbette yaygın olan nedenlerle şehrin kendi adıyla anılmasını istiyor, belki de buranın yeni bir Konstantinopolis ya da İskenderiye olabileceğini hayal ediyordu. Fakat gerek şehrin coğrafi konumunun merkeze uzaklığı, gerek imparatorluğun sınır kısmında bulunması dolayısıyla her zaman istikrarsız ve belirsiz olan konumu, gerekse de özellikle şehir isimlerinin tarihsel süreç içerisindeki evrimleri üzerinde belirleyici olan kaideler dolayısıyla bu isim fazla yaşamayacak ve Augustalı olmayı çok da benimsemedikleri anlaşılan halk tarafından bir süre sonra tarihin karanlıkları içerisinde unutulup gidecekti. ${ }^{27}$

Kronolojik olarak gidecek olursak, İslâmî dönemde şehir için kullanılan ve ortaçağlar boyunca șehrin ismi olarak öne çıkan Âmid ismi, kuşkusuz çalıșmamızın ana konusunu teșkil etmesi dolayısıyla müstakil bir başlık altında ele alınmayı hak etmektedir. Dolayısıyla, aşağıda ayrı bir başlık altında incelenmeye çalışılacaktır.

Şehri isimlendirmek için özellikle geç dönemlerde kullanılan isimlerden biri olan ve 13. Yüzyıldan sonra kaleme alınan eserlerde görülen Kara Âmid ya da Kara Hamid'e veya Timur devri zafernâmelerinde görülen Karaca Kale ve Kara Kale kullanımlarına gelince, bu isimlendirme biçiminin kuşkusuz şehir surlarının siyah olması dolayımında teşekkül ettiği açıktır. ${ }^{28}$ Nitekim Evliya Çelebi de şehrin bu şekilde isimlendirilmesinin sebebinin "müzeyyen siyah taş ile bina edilmesi" olduğuna işarette bulunmaktadır. ${ }^{29}$ Bununla birlikte, ismin bu şekildeki kullanımı ile ilgili olarak Fahrettin Kırzıoğlu tarafından şekillendirilen başka bir teorinin daha bulunduğunu not etmek gerekir. Buna göre, 13. Yüzyıl itibarıla şehir için Kara sıfatının kullanılması, Âmid'in 12. Yüzyılın sonlarından sonra Artukluların merkezi ve daha sonraları da Akkoyunluların kışlağı olarak öne çıkmasıdır. Kara kelimesi, Uygurların KaraBalgasun ya da Moğolların Kara-Kurum gibi şehirlerinde de görüldüğü gibi, Türkçede kışlakmerkez anlamlarına gelmektedir. ${ }^{30}$ Aynı şekilde Mehmet Mehdi İlhan tarafından ortaya konan ve Türklerin yer isimleri için "Kara" kelimesini çok kullanması, özellikle Diyârbekir bölgesinde de bu sıfat ile başlayan birçok yer isminin bulunması üzerinden ilerleyen yaklaşıma göre, Kara Âmid isminin Türk gelenekleri doğrultusunda oluşmuş bir isim olabileceğine ilişkin başka bir değerlendirme daha vardır. ${ }^{31}$ Yine ismin Hamid haline gelişine dair de bir çerçeve bulunmaktadır. Hiç kuşkusuz bu dönemlerde artık bölgede Türk hâkimiyetinin mevcudiyetinin

\footnotetext{
${ }^{26}$ Parla, "Osmanlı Öncesinde Diyarbakır: Kente Hakim Olanlar ve Bıraktıkları Fiziksel İzler," s. 247; Türksoy, Demir Çă̆ı'nda Diyarbakır Bölgesi, s. 1.

${ }^{27}$ Ammianus Marcellinus, I, s. 465.

${ }^{28}$ Evliya Çelebi, IV, s. 24; Bruinessen ve Boeschoten, Evliya Çelebi Diyarbekir'de, s. 191; Le Strange, Doğu Hilafetinin Memleketleri (Mezopotamya, Iran ve Orta Asya), s. 151; Beysanoğlu, Bütün Cepheleriyle Diyarbakır, s.

3; Beysanoğlu, Anıtları ve Kitâbeleri Ile Diyarbakır Tarihi, I, s. 3-4; Okumuş, "Evliya Çelebi'nin Seyahatnâme'sinde Diyarbakır," s. 175; Parla, Türk-İslam Şehri Olarak Diyarbakır, s. 21; Yılmazçelik, XIX. Yüzyılın İlk Yarısında Diyarbakır, s. 1.

${ }^{29}$ Evliya Çelebi, IV, s. 29-30; Bruinessen ve Boeschoten, Evliya Çelebi Diyarbekir'de, s. 191.

${ }^{30}$ Beysanoğlu, Bütün Cepheleriyle Diyarbakır, s. 3, n. 1; Beysanoğlu Anttları ve Kitâbeleri İle Diyarbakır Tarihi, I, s. 3; Yılmazçelik, XIX. Yüzyılın İlk Yarısında Diyarbakır, s. 1, n. 3.

${ }_{11}$ Mehmet Mehdi İlhan, "Onaltıncı Yüzyıl Başında Amid Sancağı Yer ve Şahıs Adları Hakkında Bazı Notlar,0, Belleten, C. LIV, S. 209, 1990, s. 214.
} 
güçlü bir biçimde etkili olması ile bağlantılı olarak teşekkül ettirilen bu çerçeve, Oğuz Türkmenlerinin sesli harf ile başlayan bazı isimleri başlarına " $G$ " ya da " $H$ " vokallerini getirerek söylemeleri ile ilişkilendirilmekte ${ }^{32}$ ve Türkmen ağzında Amid isminin Hamid'e dönüştüğü değerlendirilmektedir. ${ }^{33}$ Nitekim kaleme almış olduğu Ahsenü’t-Tevârîh isimli eserini Safevî hükümdarı II. Şah İsmail'e ithaf eden 16. Yüzyıl Türkmen müellifi Hasan-1 Rumlu'nun eserinde söz konusu kullanımın yer alması da buna delalet eder. ${ }^{34}$

Burada bir başka isimlendirme pratiğine daha işaret etmek gerekir ki, bu da daha önce bölgeyi tarif eden bir kelime olmasına rağmen 19. Yüzyıldan itibaren şehri tanımlamak için kullanılmaya başlanan Diyârbekir ismidir. Fatih Camii'nde ders halkası olan Âmidî nisbeli âlimlerin nereli olduklarının artık bilinmemeye başladığından şikâyet eden, hatta eski ismi de yaşatmaya devam etmek için Âmid adını taşıyan bir gazete neşreden Ali Emiri Efendi'nin "biriki asırdır Âmid isminin unutularak yerine Diyârbekir isminin kullanılmaya başladığını" belirttiği Diyârbekir ismi, ${ }^{35}$ eski dönemlerden itibaren el-Cezîre bölgesine gelip yerleşen Arap soylu Bekrîlere izafetle oluşmuştur. Bununla birlikte, özellikle Âmid şehrini tarif eden bir kelime olarak Diyârbekir ile ilgili başka değerlendirmelerin de bulunduğunu ve bu değerlendirmelerin, adı geçen şehrin eski dönemlerden itibaren Diyârbekir olarak isimlendirildiğine dair bir anlamlandırma pratiği sunma gayreti içerisinde olduklarını belirtelim. Bunlardan ilki, Diyârbekir isminin, M.Ö. 1. Yüzyılda hüküm süren Armenia Kralı Tigranes tarafından kurulduğu bilinen ve bugün yeri konusunda araştırmacılar arasında ittifak bulunmayan Tigranokerta' dan ${ }^{36}$ geldiği yönündedir. ${ }^{37}$ Hakkında külliyetli bir literatür bulunan ve bazı araştırmacılar tarafından Meyyâfârikîn (Silvan) ile eşleştirilen Tigranokerta'nın Diyârbekir isminin kökeninde yer aldığı iddiasının, söz konusu şehrin tarihsel varlığının belirsiz olması dolayısıyla güçlü bir temele sahip olmadığı görülmektedir. ${ }^{38}$ Bununla birlikte bu

\footnotetext{
32 Türkmenlerin isimleri kendi ağızlarında farklı formlara soktuklarına işaret eden bu durumun başka örnekleri de bulunmaktadır. Mesela sözü edilen kullanım biçimi ile ilişkili olarak Türkmenler, Siirt'teki Arzan kasabası ve çayını Garzan, Lice'nin merkezine karşılık gelen Atak'1 Hatak, ayva'yı hayva, ark'1 hark, avlu'yu havlu vb. şeklinde söylemekteydiler. Bkz. Beysanoğlu, Anıtları ve Kitâbeleri İle Diyarbakır Tarihi, I, s. 3.

${ }_{33}$ Beysanoğlu, Anitları ve Kitâbeleri İle Diyarbakır Tarihi, I, s. 3.

${ }^{34}$ Hasan-1 Rumlu, Ahsenü 't-Tevârîh, çev. Mürsel Öztürk, Türk Tarih Kurumu Yayınları, Ankara 2006, s. 102.

${ }^{35}$ Ali Emirî-i Âmidî, “Amid," (Âmid-i Sevdâ Gazetesi, 7 Şubat 1325), haz. Aziz Aşan, e-Şarkiyat İlmi Araştırmalar Dergisi, S. IV, 2010, s. 157-158.

${ }^{36}$ Tigranokerta şehri ve bu şehrin lokalizasyonu ile alakalı farklı değerlendirmeler için bkz. Pawstos Buzandatsi, History of the Armenians, çev. Robert Bedrosian, New York, 1985, s. 155, J. Shiel, "Notes on Journey from Tabriz, Through Kurdistan, via Van, Bitlis, Se'ertand Erbil, to Suleimaniyeh, in July and August, 1836," Journal of the Royal Geographical Society of London, 8, 1838, s. 77; Bernard W. Henderson, "Controversies in ArmenianTopography, I. The Site of Tigranocerta," The Journal of Philology, XXVIII, 1903, s. 99-121; T. Rice Holmes, "Tigranocerta," The Journal of Roman Studies, 7, 1917, s. 120-138; Ellen Churchill Semple, "The Ancient Piedmont Route of Northern Mesopotamia", Geographical Review, 8/3, 1919, s. 164, 176-177; Réne Grousset, Başlangıcından 1071'e Ermenilerin Tarihi, çev. Sosi Dolanoğlu, Aras Yayıncılık, İstanbul, 2006, s. 86; T. A. Sinclair, Eastern Turkey: An Architectural and Archeological Survey, I, The Pindar Press, Londra, 1987, s. 16, 87, 154-155; Canan Seyfeli, "Osmanlıya Kadar Diyarbakır ve Çevresinde Ermenilerin Dini Durumları," 1. Uluslararası Ŏguzlardan Osmanliya Diyarbakır Sempozyumu, 20-22 Mayıs 2004-Diyarbakır, Bildiriler Kitabı, ed. Kenan Ziya Taş, Ahmet Kankal, Diyarbakır 2004, s. 763-771.

${ }^{37}$ Urfalı Mateos Vekayi-Nâmesi (952-1136) ve Papaz Grigor'un Zeyli (1136-1162), çev. Hrant D. Andreasyan, Notlar: Edouard Dulaurer, Halil Yinanç, Türk Tarih Kurumu Yayınları, Ankara 2000, s. 257; Smbat Sparapet, Chronicle, İngilizce çev. Robert Bedrosian, New Jersey 2005, s. 5. Saîd Paşa, "Vilayetin Tarihçesi," s. 9; Günkut, Diyarbekir Tarihi, s. 38; Beysanoğlu, Anıtları ve Kitâbeleri İle Diyarbakır Tarihi, I, s. 5; Çevik, XI-XIII. Yüzyıllarda Diyâr-ı Bekr Bölgesi Tarihi, s. 6; Seyfeli, "Osmanlıya Kadar Diyarbakır ve Çevresinde Ermenilerin Dini Durumlar1," s. 764-766.

38 Tigranokerta'nın yerine ilişkin bir değerlendirme için bkz. Muzaffer Demir, “Antik Kaynaklar Işı̆̆ında Tigranokerta Şehrinin Lokalizasyonu Meselesi," I. Uluslararası Batman ve Çevresi Tarihi ve Kültürü Sempozyumu, 15-17 Nisan 2008-Batman, ed. Salim Cöhce, Adnan Çevik, Bildiriler Kitabı, Batman Valiliği Yayını, İstanbul 2009, I, s. 171-182.
} 
iddianın daha sonraki dönemlerde Ermeniler arasında yaşamaya devam ettiğini de not etmek gerekir. 16. Yüzyılda şehri ziyaret eden Polonyalı Simeon'un "kral ve patriklerin payitaht şehri" olarak nitelendirdiği Âmid surlarından "Tigran binası" şeklinde söz etmesi bununla ilgilidir. ${ }^{39}$

Diyârbekir ismini anlamlandırmaya dönük başka teșebbüsler de bulunmaktadır. Sözü edilen teşebbüslerin ilki, ismin Darabkerd kelimesinden geldiği yönündedir. Mehmed Hafid tarafından nakledilen bu bilgiye göre, İran hükümdarı Darab burayı inşa ettirdiği için şehre Darabkerd adı verilmiş ve bu isim daha sonraları Diyârbekir'e dönüşmüştür. ${ }^{40}$ Bir başka görüş Diyârbekir isminin, bölgeye Partlarla birlikte gelen Derbik Türklerinden dolayı şehre verildiği yönündedir ve şehrin tarihi ile ilgili en önemli metinlerin ikisini kaleme alan Basri Konyar ile Bedri Günkut tarafından ileri sürülmüştür. ${ }^{41}$ Aynı şekilde Şevket Beysanoğlu tarafından ortaya konulmuş olan bir başka görüş daha vardır ki, burada ona da temas etmek yerinde olacaktır. Onun bildirdiğine göre, Diyârbekir ismi, 3 Ağustos 1869 tarihinde haftalık çıkmaya başlayan Diyârbekir isimli resmî vilayet gazetesi ve memurların bu ismi kullanma eğilimleri yüzünden bu dönemde Âmid'e ilave olarak kullanılır olmuştur. ${ }^{42}$

Diyârbekir isminin kaynağına ilişkin bir diğer görüş, söz konusu ismin bir zamanlar Urfa Kapı yakınında bulunan büyük Rum kilisesi ile ilișkili olduğu fikrine istinat eder. Buna göre, Benî Meryem adını taşıyan bu "kız kilisesi," Müslümanların şehri fethetmesinden sonra "Bâkire kızın yeri" anlamını taşıyan Dâru'l-Bâkire ya da Diyâru'l-Bâkire adıyla bilinmeye başlamış ve bu kullanım zaman içerisinde dönüşüm geçirerek Diyârbekir haline gelmiştir. ${ }^{43}$ İsmi kız ve bâkire kelimelerinden hareketle açıklamaya çalışan tek görüş bu değildir. Evliya Çelebi tarafindan nakledilen bir rivayete göre uzun süre irşad etmeye çalıştığ 1 Musullulardan beklediğini bulamayan Hz. Yunus onlara beddua edip Musul'dan ayrılarak Âmid şehrinin de yer aldığı bölgeye gelmiş ve bölge halkı kendisinden hiçbir mucize talebinde bulunmadan hak olan davetini kabul etmiştir. Burada yedi yıl ikamet eden Peygamber'e iman edenler arasında bölge hâkimi olan bir kız da vardır ve bu kız, Hz. Yunus'un kendisine öğrettiği şekliyle bugün de aynı isimle anılmaya devam eden Fis kayası üzerinde bir şehir kurduğu için burası onun adıyla Diyar-1 Bikr (Kız Diyarı) olarak anılmış, zaman içerisinde Diyârbekir'e dönüşmüştür. ${ }^{44}$ Yine aynı temele dayanan son görüş Süryanî geleneğine aittir ve Diyârbekir isminin Süryanî dilinde "kilise" demek olan "Deyr" ile yine aynı dilde "kı" anlamında gelen "Bakira/Bikre" kelimelerinden teşekkül eden ve burada kurulmuş ilk kilisenin adı olan "Deyre'l-Bikre"den türediğini ileri sürmektedir. ${ }^{45}$

Diyârbekir ismi ile alakalı en sıra dışı görüş, kelimeyi İbranice bir temele dayandırma iddiasında olan yaklaşımdır. İbranî dilinde "şehir" anlamına gelen "Diyar," "içinde" anlamına gelen "be" ve "duvar" anlamına gelen "kir" kelimelerinin bir araya gelmesi ile sözü edilen bu

\footnotetext{
${ }^{39}$ Polonyalı Simeon, Polonyalı Bir Seyyahın Gözünden 16. Asır Türkiyesi, çev. Hrand D. Andreasyan, Sadeleştiren: İslam Özkan, Köprü Kitap, İstanbul 2016, s. 138.

${ }^{40}$ Beysanoğlu, Anıtları ve Kitâbeleri İle Diyarbakır Tarihi, I, s. 5.

${ }^{41}$ Günkut, s. Diyarbekir Tarihi, 38-39, 47-48; Beysanoğlu, Anttları ve Kitâbeleri İle Diyarbakır Tarihi, I, s. 5.

42 Beysanoğlu, Bütün Cepheleriyle Diyarbakır, s. 4.

${ }^{43}$ Günkut, Diyarbekir Tarihi, s. 38; Parla, Türk-İslam Şehri Olarak Diyarbakır, s. 22; Cuma Karan, "Diyarbakır'ın İsmi ve Fethi Üzerine Bazı Mülahazalar," 1. Uluslararası Oğuzlardan Osmanlıya Diyarbakır Sempozyumu, 20-22 Mayıs 2004-Diyarbakır, ed. Kenan Ziya Taş, Ahmet Kankal, Bildiriler Kitabı, Diyarbakır 2004, s. 827.

${ }^{44}$ Evliya Çelebi, IV, s. 24; Bruinessen ve Boeschoten, Evliya Çelebi Diyarbekir'de, s. 190-191; Günkut, Diyarbekir Tarihi, s. 37; Okumuş, Okumuş, "Evliya Çelebi'nin Seyahatnâme'sinde Diyarbakır," s. 175; Muharrem Yıldız, "Diyarbakır'da Hıristiyan Rumlardan Arda Kalanlar," Nebiler, Sahabiler, Azizler ve Krallar Kenti Diyarbakır Sempozyuтu, 25-27 Mayıs 2009-Diyarbakır, Bildiriler Kitabı, Ankara 2010, s. 194; Karan, ““'Diyarbakır'ın İsmi ve Fethi Üzerine Bazı Mülahazalar,” s. 828.

${ }^{45}$ Karan, "Diyarbakır'ın İsmi ve Fethi Üzerine Bazı Mülahazalar,” s. 828.
} 
ismin meydana geldiğini ve "Duvar içindeki şehir" demek olduğunu savlayan bu yaklaşımın pek kabul görmüş olmamakla birlikte, örneğin bir yazar tarafından benimsenerek aynı adda bir romana isim olarak verildiğini kayıt altına almak, herhalde bu bölümü zenginleştiren hoş bir katk1 olacaktır. ${ }^{46}$

$\mathrm{Bu}$ bahis içerisinde son olarak Diyarbakır isminden de bahsetmek gerekir. Halen şehre ad olan bu isim, ilk olarak, 15 Kasım 1937 tarihinde şehri ziyaret eden ve bu ziyaret onuruna halk evinde tertip edilen kutlamada yaptığı konuşma sırasında Türkiye Cumhuriyeti'nin banisi Mustafa Kemal Atatürk tarafindan kullanılmış ve Diyârbekir olan şehrin ismi, hemen ertesi gün atılan adımlarla resmîleştirilerek Diyarbakır'a çevrilmiştir. ${ }^{47}$

\section{Müslüman Âmid'e Dâir}

Âmid ismi ile alakalı olarak her ne kadar elimizde eski dönemlere uzanan ve önemli ölçüde sahih olduğunu belirtmekte sakınca bulunmayan tarihsel bir çerçeve mevcut olmakla birlikte, uzun yıllar boyunca şehre hâkim olan Müslümanların şehrin kendisi gibi ismini de İslâmlaştırdıkları ve Âmid ismini bir tür İslâmî isme dönüştürdükleri görülmektedir. Nitekim gerek şehrin ismine, gerekse kuruluşuna dair İslâm kültüründen beslenen muhtelif rivayetlerin ortaya çıkmış olmasını da buna bağlamak gerekir. Örneğin Âmid yakınlarında bulunan tarihî Meyyâfârikîn (Silvan) şehri başta olmak üzere, Müslümanlar tarafindan fethedildikten sonra zamanla bir İslâm şehri haline gelen birçok yerleşim biriminde görüldüğü gibi, şehre dâir her şey İslâmî bir anlam çerçevesi içerisine dâhil edilmiş, bu manada şehrin şimdisi olduğu kadar geçmişi de İslâmîleştirilmiş̧ir.

Kaynaklarımızda, yazılışına dâir Arapça bir çerçeve çizildiğini de gördüğümüz Âmid ${ }^{48}$ ismi hakkında birtakım yaklaşımlar bulunmaktadır. Bunların ilkinin, 487/1094 senesinde Kurtuba'da vefat eden Müslüman coğrafyacı Bekrî’ye ait olduğu söylenebilir. Âmid isminin okunuşu ile alakalı açık bir tarif veren müellifin Muhammed b. Sehl isimli râvîden naklettiği bilgiye bakılırsa, şehrin isminin kaynağı Hz. İbrahim'in oğlu Medyen'in oğlu Belenda'nın oğlu Âmid'e kadar gitmektedir. ${ }^{49}$ Âmid ismine ilişkin bu açıklamanın ihtiyatla karşılanması gerektiği açıktır. Öte taraftan, sözünü ettiğimiz ihtiyat noktasına da şerh düşmekle birlikte, açıklamanın doğru olabilme ihtimaline dair fikir beyan eden araştırmacıların bulunduğunu da not edelim. ${ }^{50}$ Burada bir kayda daha temas etmekte yarar vardır ki, o da 1234 yılında Halep'te vefat eden İbn Şeddâd'ın kaydıdır. Onun bildirdiğine göre, Âmid isminin kaynağı, bu bölgeye gelip yerleşenlerin ilklerinden olan Âmid b. el-Belendî b. Malik b. Ze'r isimli bir zattır. Yine aynı müellif tarafından nakledilen bir başka rivayet, aynı şeyin eş-Şarkî b. el-Kutâmî isimli bir

\footnotetext{
${ }^{46}$ Karan, “Diyarbakır'ın İsmi ve Fethi Üzerine Bazı Mülahazalar,” s. 827.

${ }^{47}$ Bahaeddin Yediyıldız, "Osmanlı Öncesi Diyarbakır'ına Genel Bir Bakış," Osmanlı'dan Cumhuriyet'e Diyarbakır, I, ed. Bahaeddin Yediyıldız, Kerstin Tomenendal, Diyarbakır Valiliği ve Türk Kültürü'nü Araştırma Enstitüsü Yayını, Ankara 2008, s. 18; Süer Eker, "Türk Dili Tarihinde Bir Dilbilimsel Temas Bölgesi Olarak Diyarbakır," Osmanlı'dan Cumhuriyet'e Diyarbakır, I, ed. Bahaeddin Yediyıldız, Kerstin Tomenendal, Diyarbakır Valiliği ve Türk Kültürü’nü Araştırma Enstitüsü Yayını, Ankara 2008, s. 96; Karan, "Diyarbakır'ın İsmi ve Fethi Üzerine Bazı Mülahazalar," s. 829; Kenan Haspolat, "Hükümdarlar, Paşalar ve Beyler Kenti Diyarbakır," Nebiler, Sahabiler, Azizler ve Krallar Kenti Diyarbakır Sempozyumu, 25-27 Mayıs 2009-Diyarbakır, Bildiriler Kitab1, Ankara 2010, s. 301-302.

${ }^{48}$ Yâkût el-Hamevî, I, s. 56-57; Bekrî, II, s. 93; Kalkaşandî, IV, s. 324.

${ }^{49}$ Bekrî, II, s. 93. Şehrin ismini Hz. İbrahim ile ilişkilendiren bu rivayet ile alakalı nispeten detaylı bir çözümleme için bkz. Günkut, Diyarbekir Tarihi, s. 39-41.

50 Abdulhalik Bakır, "Klasik İslam Kaynaklarında Amid (Diyarbakır) İle İlgili Kayıtlar ve Bu Kayıtların Değerlendirilmesi," 1. Uluslararası Oğuzlardan Osmanliya Diyarbakır Sempozyumu, 20-22 Mayıs 2004-Diyarbakır, ed. Kenan Ziya Taş, Ahmet Kankal, Bildiriler Kitabı, Diyarbakır 2004, s. 838; Karan, "Diyarbakır'ın İsmi ve Fethi Üzerine Bazı Mülahazalar,” s. 827.
} 
kimse için de söylendiği yönündedir. ${ }^{51}$ Bunlara benzer niteliklere sahip başka bir rivayet daha vardır ki, o da Âmid isminin bir zaman bölgeye iskân edilmiş olan Benî-Âmid isimli bir Arap kabilesinden hatıra kaldığ 1 şeklindedir. ${ }^{52}$ Âmid isminin kökenini bir kişiye ya da soya bağlayan bu türden rivayetlerin yakıştırma oldukları muhtemel olmakla birlikte, bunlar, halk arasında şehrin adına dönük bir merak duygusunun var olduğunu ve bunu gidermek için de çeşitli anlamlandırma girişimlerinin dolaşıma girdiğini göstermesi açısından dikkate değer örneklerdir.

Âmid ismi ile alakalı olarak İslâm kaynaklarında yer alan bir başka çözümleme biçimi, 626/1229 yılında Halep'te vefat eden Yâkût el-Hamevî'nin benzersiz ansiklopedik çalışması Mu'cemu'l-Büldân'da yer almaktadır. El-Cezîre coğrafyasının uç bölümünde yer alan Âmid şehrinin isminin Rumca olduğunu tahmin ettiğini bildiren Yâkût el-Hamevî'ye göre, bu ismin, "el-emed" kelimesinin "çok fazla" anlamına gelmesi dolayısıyla Arap dilinde çok güzel bir kökü vardır. Bir kimsenin aşırı derece öfkelenmesi durumunda kullanılmakta olup ism-i fâil sığasında olan "Âmid" kelimesi, "çok fazla öfkelenen kişi” anlamına gelmektedir. Böyle bir ismin şehre isim olarak verilmesine gelince, bunun nedeni ise Âmid'in, güzelliği dolayısıyla kendisine sahip olmak isteyenleri sarp bir konumda bulunması sebebiyle kızdırmasıdır. Yine ismin müzekker (eril) olması da, Arapçada bir bölge ya da yer için kullanılan isimlerin müzekker kullanımlara sahip olması dolayısıyla, Âmid kelimesiyle alakalı değerlendirmeyi desteklemektedir. ${ }^{53}$

Âmid ismini açıklamaya çalışan bir başka yaklaşım girişimi, Yâkût el-Hamevî’nin de işaret etmiş olduğu kelimenin "uç, sınır, intiha" şeklindeki anlamından hareketle meydana getirilmiş görünmektedir. Bölge ile alakalı en önemli referans kaynakları arasında yer alan bir eser de kaleme almış olan Said Paşa tarafından benimsenen bu yaklaşım, temelde, kuşkusuz ismin kelime anlamından hareket edilmek suretiyle, İslâm coğrafyasının suğûr bölgesine karşılık gelen ve uç noktasında bulunan el-Cezîre'nin "ihtihasındaki" şehir olması hasebiyle Arapların burayı Âmid olarak adlandırdığı yönündedir. ${ }^{54}$ Şehrin uzun yıllar boyunca bir sınır kenti, bir tür garnizon olarak işlev gördüğü düşünüldügünde, söz konusu yaklaşımın dikkate değer olduğu açık bir biçimde ortaya çıkmaktadır.

Son olarak erken dönem İslâm tarihçiliğinin önemli isimleri arasında olan Vâkıdî’nin (ö. 823) zikrettiği ilginç bir rivayet, Âmid ismine ilişkin farklı bir yaklaşım ortaya koymaktadır. Buna göre, bir zamanlar Kostantiniyye'yi inşa edip burayı oğlunun adıyla isimlendiren Bizanslıların hükümdarı ülkesinin sınırları içerisinde bulunan Diyârbekir'in güzelliğinden çok etkilenmiş ve burada Kostantiniyye'ye benzeyen güzel bir şehir inşa edilmesini emretmiştir. Hükümdarın emriyle başlayan çalışmalar sonucu şehir hızla inşa edilmeye başlanmakla birlikte, onun ömrü inşaat faaliyetlerinin sona ermesini görmeye yetmemiş ve bundan dolayı şehre bu anlamdaki Âmid kelimesi isim olmuştur. ${ }^{55}$ Şehrin ismini Bizans geleneği ile ilişkilendiren elVâkıdî’nin rivayeti özgün bir rivayet olma özelliğine sahip olması bakımından önemlidir.

\footnotetext{
${ }^{51}$ İbn Şeddâd, el-A 'lâku'l-Hatîra Fî Zikri Ümerâi'ş-Şâm ve'l-Cezîre, III, thk. Yahya Abbare, Dımaşk, 1968, s. 253.

${ }^{52}$ Saîd Paşa, "Vilayetin Tarihçesi," s. 8; Karan, "Diyarbakır'ın İsmi ve Fethi Üzerine Bazı Mülahazalar," s. 826.

${ }^{53}$ Yâkût el-Hamevî, I, s. 56. Yâkût'un eserinin bir özeti olduğu bilinen Merâsıdu'l-Ittilâ' da da kelimenin Rumca olduğu bilgisine yer verilmektedir. Bkz. el-Bağdâdî, I, s. 6. Ayrıca bkz. Günkut, Diyarbekir Tarihi, s. 37; Bakır, "Klasik İslam Kaynaklarında Amid (Diyarbakır) İle İlgili Kayıtlar ve Bu Kayıtların Değerlendirilmesi," s. 838.

${ }^{54}$ Yâkût el-Hamevî, I, s. 56; Saîd Paşa, "Vilayetin Tarihçesi," s. 8; Günkut, Diyarbekir Tarihi, s. 37-38; Karan, "Diyarbakır'ın İsmi ve Fethi Üzerine Bazı Mülahazalar," s. 826.

55 Muhammed b. Ömer b. Vâkıd el-Vâkıdî, Fütûhu'ş-Şâm, II, thk. Taha Abdurrauf Sa'd, Hâdî el-Hâc, elMektebetü’t-Tevfîkiyye, y.y., trs., s. 189-190; Karan, "Diyarbakır'ın İsmi ve Fethi Üzerine Bazı Mülahazalar," s. 827.
} 


\section{Sonuç}

Binlerce yıllık bir tarihî geçmişe sahip olan Diyarbakır'ın uzun tarihî serüveninde birçok isimle anıldığı bilinmektedir. Antik Mezopotamya'da kullanılan Amedi ile başlayan bir sürecin nihai noktada Diyarbakır ile sonuçlanması olarak görülebilecek olan bu şehrin isim tarihi, giriş kısmında kısaca temas etmiş olduğumuz isim verme biçimleri açısından gerçek bir laboratuvar gibidir. Metin içerisinde gösterildiği üzere birçok isimle anılmış, bu isimlerin her birinin de kısa ya da uzun bir ömrü olmuştur. Âmid'in tarih boyunca aldığı isimler açısından en dikkat çekici olan husus, ilk olarak şehre ad olduğu tespit edilebilen Amedi'nin şu ya da bu biçimde sonraki isimlerin büyük bölümünde bir şekilde yaşamaya devam etmiş olmasıdır. Öte yandan Bizans İmparatoru tarafından verilen ismin kabul görmemenin yanında kısa süre içerisinde unutulmuş olmasını istisna olarak görmek gerekir. Yine bugün Diyarbakır isminde bir yanıyla yaşamaya devam eden Diyârbekir adlandırmasının ise temelde bölgenin adı ile bölgenin merkezini teşkil eden şehrin adı arasında zaman içerisinde bir paralellik oluşması şeklinde görmek çok yerinde bir bakış olacaktır. Son olarak Âmid isminin ise şehrin kuruluş döneminden itibaren bazı kısa aralıklarla yerini başka isimlere bırakmış olmakla birlikte her zaman yaşamaya devam ettiğini, bugün halen halk arasında bozulmuş bir biçimde de olsa varlığını sürdürdüğünü ve nihayetinde de şehrin tarihî serencamını en belirgin haliyle aksettiren temel isim olduğunu belirtelim.

\section{Kaynakça}

Abû'l-Farac, Gregory (Bar Hebraeus), Abû'l-Farac Tarihi, I, Süryaniceden İngilizceye çev. Ernest A. Wallis Budge, Türkçe çev. Ömer Riza Doğrul, Türk Tarih Kurumu Yayınları, Ankara 1999.

Ali Emirî-i Âmidî, "Amid," (Âmid-i Sevdâ Gazetesi, 7 Şubat 1325), haz. Aziz Așan, eŞarkiyat Illmi Araştırmalar Dergisi, S. IV, 2010, s. 181-191.

Ammianus Marcellinus, I, çev. John C. Rolfe, ed. T. E. Page, E. Capps, W. H. D. Rouse, Büyük Britanya, 1935.

Bakır, Abdulhalik, "Klasik İslam Kaynaklarında Amid (Diyarbakır) İle İlgili Kayıtlar ve Bu Kayıtların Değerlendirilmesi," 1. Uluslararası Oğuzlardan Osmanliya Diyarbakır Seтроzуити, 20-22 Mayıs 2004-Diyarbakır, ed. Kenan Ziya Taş, Ahmet Kankal, Bildiriler Kitab1, Diyarbakır 2004, s. 837-848.

Bekrî, Ebû Ubeyd Abdullah b. Abdülazîz, Mu'cem Ma'ste'cem Min Esmâi'l-Bilâdi ve'lMevâzl', II, thk. Mustafa es-Sekâ, Beyrut, trs.

Beysanoğlu, Şevket, Bütün Cepheleriyle Diyarbakır, Diyarbakır Sanayi ve Ticaret Odası Yayınları, İstanbul 1963.

Beysanoğlu, Şevket, Anıtları ve Kitâbeleri İle Diyarbakır Tarihi, I, Başlangıçtan Akkoyunlulara Kadar, Diyarbakır Büyükşehir Belediyesi Kültür ve Sanat Yayınları, Ankara 1998.

Çevik, Adnan, XI-XIII. Yüzyıllarda Diyâr-ı Bekr Bölgesi Tarihi, (Yayınlanmamış Doktora Tezi), Marmara Üniversitesi Türkiyat Araştırmaları Enstitüsü, İstanbul 2002.

Darkot, Besim, "Diyarbekir", $\dot{I} A$, III, Milli Eğitim Bakanlığı, y.y., trs., s. 601-605.

Demir, Muzaffer, "Antik Kaynaklar Işı̆̆ında Tigranokerta Şehrinin Lokalizasyonu Meselesi," I. Uluslararası Batman ve Çevresi Tarihi ve Kültürü Sempozyumu, 15-17 
Nisan 2008-Batman, ed. Salim Cöhce, Adnan Çevik, Bildiriler Kitabı, Batman Valiliği Yayını, İstanbul 2009, I, s. 171-182.

Eker, Süer, "Türk Dili Tarihinde Bir Dilbilimsel Temas Bölgesi Olarak Diyarbakır," Osmanlı'dan Cumhuriyet'e Diyarbakır, I, ed. Bahaeddin Yediyıldız, Kerstin Tomenendal, Diyarbakır Valiliği ve Türk Kültürü’nü Araştırma Enstitüsü Yayını, Ankara 2008, s. 91-110.

el-Bağdâdî, Safiyyüddîn Abdülmümin b. Abdülhakk, Merâsıdu'l-Ittilâ' Alâ Esmâi'lEmkineti ve'l-Bekâ', I, thk. Ali Muhammed el-Becâvî, Beyrut 1992.

el-Hüseynî, Ca'ferî b. Muhammed, Târîh-i Kebîr (Tevârîh-i Enbiyâ ve Mülûk), çev. İsmail Aka, Türk Tarih Kurumu Yayınları, Ankara 2011.

el-İsfahânî, İmâdeddîn Muhammed b. Muhammed b. Hâmid el-Kâtib, el-Berku'ş-Şâmî, $V$, nşr. Ramazan Şeşen, İstanbul Üniversitesi Edebiyat Fakültesi Yayınları, İstanbul 1979.

el-Kalkaşendî, Şeyh Ebû'l-Abbâs Ahmed, Subhu'l- 'Aşâ, IV, Kahire, 1914-1945.

el-Vâkıdî, Muhammed b. Ömer b. Vâkıd, Fütûhu'ş-Şâm, II, thk. Taha Abdurrauf Sa'd, Hâdî el-Hâc, el-Mektebetü’t-Tevfîkiyye, y.y., trs.

Evliya Çelebi, Seyahatnâme, IV, İkdam Matbaası, 1314.

Gabriel, Albert, Şarki Türkiye'de Arkeolojik Geziler, çev. İdil Çetin, Dipnot Yayınları, Ankara, 2014.

Gibbon, Edward, Roma Imparatorluğu'nun Gerileyiş ve Çöküş Tarihi, II, çev. Asım Baltacıgil, B/F/S Yayınları, İstanbul 1987.

Göğünç, Nejat, "Onaltıncı Yüzyılın İlk Yarısında Diyarbakır," Belgelerle Türk Tarihi Dergisi, 7, 1968, s. 76-80.

Grousset, Réne, Başlangıcından 1071'e Ermenilerin Tarihi, çev. Sosi Dolanoğlu, Aras Yayıncılık, İstanbul, 2006.

Günkut, Bedri, Diyarbekir Tarihi, Diyarbekir Basımevi, Diyarbakır, trs.

Hasan-1 Rumlu, Ahsenü't-Tevârîh, çev. Mürsel Öztürk, Türk Tarih Kurumu Yayınları, Ankara 2006.

Haspolat, Kenan, "Hükümdarlar, Paşalar ve Beyler Kenti Diyarbakır," Nebiler, Sahabiler, Azizler ve Krallar Kenti Diyarbakır Sempozyumu, 25-27 Mayıs 2009-Diyarbakır, Bildiriler Kitab1, Ankara 2010, s. 233-313.

Henderson, Bernard W., "Controversies in ArmenianTopography, I. The Site of Tigranocerta," The Journal of Philology, XXVIII, 1903, s. 99-121.

Holmes, T. Rice, “Tigranocerta,” The Journal of Roman Studies, 7, 1917, s. 120-138.

İbn Şeddâd, el-A'lâku'l-Hatîra Fî Zikri Ümerâi'ş-Şâm ve'l-Cezîre, III, thk. Yahya Abbare, Dımaşk 1968.

İlhan, Mehmet Mehdi, "Onaltıncı Yüzyıl Başında Amid Sancağı Yer ve Şahıs Adları Hakkında Bazı Notlar,0, Belleten, C. LIV, S. 209, 1990, s. 213-232.

Karan, Cuma, "Diyarbakır'ın İsmi ve Fethi Üzerine Bazı Mülahazalar," 1. Uluslararası Oğuzlardan Osmanliya Diyarbakır Sempozyumu, 20-22 Mayıs 2004-Diyarbakır, ed. Kenan Ziya Taş, Ahmet Kankal, Bildiriler Kitabı, Diyarbakır 2004, s. 825-835. 
Le Strange, Guy, Doğu Hilafetinin Memleketleri (Mezopotamya, Iran ve Orta Asya), çev. Cengiz Tomar, Adnan Eskikurt, Yeditepe Yayınları, İstanbul 2015.

Mor Efrem, Kilise Ataları Tarafindan "Kutsal Ruh'un Kavalı" Olarak Adlandirllan Mor Efrem'in Şiirleri, I, (Tıpkıbasım ve tercüme), çev. Horiepiskopos Gabriel Akyüz, Kültür Bakanlığı Yayınları, Ankara 2012.

Parla, Canan, Türk-İslam Şehri Olarak Diyarbakır, (Yayınlanmamış Yüksek Lisans Tezi), Hacettepe Üniversitesi Sosyal Bilimler Enstitüsü, Ankara 1990.

Macbean, Alexander, A Dictionary of Ancient Geography, London 1773.

Melek, Ali, "Diyarbakır'da Peygamber Makam ve Kabirleri," Nebiler, Sahabiler, Azizler ve Krallar Kenti Diyarbakır Sempozyumu, 25-27 Mayıs 2009-Diyarbakır, Bildiriler Kitab1, Ankara 2010, s. 349-362.

Nizâmüddîn Şâmî, Zafernâme, çev. Necati Lugal, Türk Tarih Kurumu Yayınları, Ankara 1987.

Okumuş, Ejder, “Evliya Çelebi'nin Seyahatnâme'sinde Diyarbakır," Osmanlı'dan Cumhuriyet'e Diyarbakır, I, ed. Bahaeddin Yediyıldız, Kerstin Tomenendal, Diyarbakır Valiliği ve Türk Kültürü'nü Araştırma Enstitüsü Yayını, Ankara 2008, s. 173-186.

Özcoşar, İbrahim, “Diyarbakır'ın Kadim Cemaati: Süryaniler,” Nebiler, Sahabiler, Azizler ve Krallar Kenti Diyarbakır Sempozyumu, 25-27 Mayıs 2009-Diyarbakır, Bildiriler Kitab1, Ankara 2010, s. 171-178.

Parla, Canan, "Osmanlı Öncesinde Diyarbakır: Kente Hakim Olanlar ve Bıraktıkları Fiziksel İzler," 1. Uluslararası Oğuzlardan Osmanlıya Diyarbakır Sempozyumu, 20-22 Mayıs 2004-Diyarbakır, Bildiriler Kitabı, ed. Kenan Ziya Taş, Ahmet Kankal, Diyarbakır 2004, s. 247-283.

Pawstos Buzandatsi, History of the Armenians, çev. Robert Bedrosian, New York, 1985.

Polonyalı Simeon, Polonyalı Bir Seyyahın Gözünden 16. Asır Türkiyesi, çev. Hrand D. Andreasyan, Sadeleştiren: İslam Özkan, Köprü Kitap, İstanbul 2016.

Saîd Paşa, "Vilayetin Tarihçesi," Salnâme-i Vilâyet-i Diyârbekir, Dersaâdet 1302.

Semple, Ellen Churchill, "The Ancient Piedmont Route of Northern Mesopotamia", Geographical Review, 8/3, 1919, s. 164, 176-177.

Seyfeli, Canan, "Osmanlıya Kadar Diyarbakır ve Çevresinde Ermenilerin Dini Durumları," 1. Uluslararası Oğuzlardan Osmanliya Diyarbakır Sempozyumu, 20-22 Mayls 2004Diyarbakır, Bildiriler Kitabı, ed. Kenan Ziya Taş, Ahmet Kankal, Diyarbakır 2004, s. 763-771.

Shiel, J., "Notes on Journey from Tabriz, Through Kurdistan, via Van, Bitlis, Se'ertand Erbil, to Suleimaniyeh, in July and August, 1836," Journal of the Royal Geographical Society of London, 8, 1838, s. 54-101.

Sinclair, T. A., Eastern Turkey: An Architectural and Archeological Survey, I, The Pindar Press, Londra 1987.

Smbat Sparapet, Chronicle, İngilizce çev. Robert Bedrosian, New Jersey 2005. 
Tavernier, Jean-Baptiste, Tavernier Seyahatnamesi, çev. Teoman Tunçdoğan, Kitap Yayınevi, İstanbul 2006.

Tezcan, Mehmet, "Hunların Anadolu'daki İlk Görünüşleri: 359 Tarihinde Amida Kuşatmasında Kionitler," 1. Uluslararası Oğuzlardan Osmanliya Diyarbakır Sempozyumu, 20-22 Mayıs 2004-Diyarbakır, Bildiriler Kitabı, ed. Kenan Ziya Taş, Ahmet Kankal, Diyarbakır 2004 s. 103-115.

Tezgel, Recep, “1869-1969 Arası Diyarbakır'da Süreli Yayınc1lık,” Uluslararası Diyarbakır Sempozyumu, 02-05 Kasım 2016-Diyarbakı, Bildiriler Kitabı, ed. Ufuk Bircan, Aytaç Coşkun, Mustafa Temel, Pınar Gürhan Kılıç, Diyarbakır 2017, s. 10971113.

Türksoy, Tuğba, Demir Çağı'nda Diyarbakır Bölgesi, (Yayınlanmamış Yüksek Lisans Tezi), Marmara Üniversitesi Sosyal Bilimler Enstitüsü, İstanbul 2007.

Umar, Bilge, Türkiye'deki Tarihsel Adlar, İnkılap Kitabevi, İstanbul 1993.

Urfalı Mateos Vekayi-Nâmesi (952-1136) ve Papaz Grigor'un Zeyli (1136-1162), çev. Hrant D. Andreasyan, Notlar: Edouard Dulaurer, Halil Yinanç, Türk Tarih Kurumu Yayınları, Ankara 2000.

van Max, Berchem, Josef Strzygowski, Gertrude Lowthain Bell, Amida, çev. Fatih Aygün, Bülent Özçelik, Hanide Türkseven, S. Erdem Türközü, Oriant Yayınları, Ankara 2015.

van Bruinessen, Martin, Hendrik Boeschoten, Evliya Çelebi Diyarbekir'de, İletişim Yayınları, İstanbul 2009.

Yâkût el-Hamevî, Mu'cemu'l-Büldân, I, thk. İhsan Abbas. Beyrut, 1977.

Yalçın, Asnu-Bilban, "VI. Yüzyılda Roma İmparatorluğu'nun Doğu Sınırları ve Amida (Diyarbakır) Kenti”, 1. Uluslararası Oğuzlardan Osmanliya Diyarbakır Sempozyumu, 20-22 Mayıs 2004-Diyarbakır, Bildiriler Kitabı, ed. Kenan Ziya Taş, Ahmet Kankal, Diyarbakır 2004, s. 225-235.

Yediyıldız, Bahaeddin, "Osmanlı Öncesi Diyarbakır'ına Genel Bir Bakış," Osmanlı'dan Cumhuriyet'e Diyarbakır, I, ed. Bahaeddin Yediylldiz, Kerstin Tomenendal, Diyarbakır Valiliği ve Türk Kültürü’nü Araştırma Enstitüsü Yayını, Ankara 2008, s. 17-36.

Yıldırım, Ercüment, Pers Hakimiyetinin Bitiminden Bizans Hakimiyetinin Başlangıcına Kadar Olan Dönemdeki Antik Çă̆ Yazarlarının Eserlerinde Orta Fırat Bölgesi, (Yayınlanmamış Doktora Tezi), Selçuk Üniversitesi Sosyal Bilimler Enstitüsü, Konya 2011.

Yıldırım, Nurgül, "Yeni Asurca Belgelerde Geçen Amēdi Şehri," Ankara Üniversitesi Dil ve Tarih-Coğrafya Dergisi, C. 53, S. 2, 2012, s. 1-19.

Yıldız, Muharrem, "Diyarbakır'da Hiristiyan Rumlardan Arda Kalanlar," Nebiler, Sahabiler, Azizler ve Krallar Kenti Diyarbakır Sempozyumu, 25-27 Mayıs 2009Diyarbakır, Bildiriler Kitabı, Ankara 2010, s. 194; Karan, ““'Diyarbakır'ın İsmi ve Fethi Üzerine Bazı Mülahazalar,” s. 193-205.

Yılmazçelik, İbrahim, XIX. Yüzyılın İlk Yarısında Diyarbakır, Türk Tarih Kurumu Yayınlar1, Ankara 1995. 
Şehre Ad Vermek: Âmid İsmi Hakkında

Yousif, Ephrem-Isa, Mezopotamya'nın Yıldız Şehirleri, çev. Nihat Nuyan, Avesta Basın Yayın, İstanbul 2011. 